\title{
Assessment of Green Gram Varieties for Better Yield in Palamu District of Jharkhand
}

\author{
Rajiv Kumar* \\ Krishi Vigyan Kendra, Palamu-822102, Birsa Agricultural University, \\ Ranchi, Jharkhand, India \\ *Corresponding author
}

\begin{tabular}{|c|}
\hline Keywords \\
\hline $\begin{array}{l}\text { Green gram, } \\
\text { Varieties, Extension } \\
\text { gap, Technology, } \\
\text { Yield }\end{array}$ \\
\hline Article Info \\
\hline $\begin{array}{l}\text { Accepted: } \\
15 \text { August } 2020 \\
\text { Available Online: } \\
10 \text { September } 2020\end{array}$ \\
\hline
\end{tabular}

\section{A B S T R A C T}

Pulses have been traditionally recognized as an indispensable constituent of Indian diet and an important source of protein for the poor as well as for the vegetarians who constitute major population of the country. The major pulses grown in Kharif season are Arhar (Pigeon Pea) and Moong (Green Gram) Urd (Black gram) and Kulthi (Horse Gram) and in rabi season include chickpea, lentil, mungbean (Summer), urd bean. India is the largest producer as well as consumer of pulses, and is the largest importer in the world. The situation in India is very alarming due to high demand and low supply of the pulses. To cope this situation the government of India initiated efforts to boost the pulse production through cluster front line demonstration through Krishi Vigyan Kendra which already doing Front Line Demonstration of improved varieties of green gram namely IPM 02-03, SML 668 and HUM 16 and boosting production. The data like average number of branches, pods/plant, grain/pod, disease incidence (\%) and grain yield (q/ha) were recorded during investigation. Among all the varieties assessed, variety IPM 02-03 proved to be the best with highest number of pods/plant (38.1) and minimum incidence of yellow mosaic disease of 6.6 per cent resulting in the highest yield of $15.7 \mathrm{q} /$ ha followed by SML668 with disease incidence of 7.9 per cent , 34.6 pods/plant and yield of 14.2 q/ ha. Hence, it was inferred that IPM 02-03 variety of green gram proved better followed by SML668.

\section{Introduction}

Pulses are important food crops for human consumption and animal feed. Being leguminous in nature, they are considered to be important components of cropping systems because of their viability to fix atmospheric nitrogen, add substantial amounts of organic matter to the soil and produce reasonable yields with low inputs under harsh climatic and soil conditions. India is the largest producer, consumer and importer of pulses in the world. It accounts for 33 per cent of world area and 22 per cent of the total world production of pulses (Sandhu and Dhaliwal, 2016).

Pulses are good and cheaper source of protein, which indicate the great importance of pulses in their daily food habits. Green 
gram (Vigna radiate L. Wilczek.) is the third important pulse crop in India. It can be grown both as Kharif green gram and summer green gram. Green gram has strong root system and capacity to fix the atmospheric nitrogen into the soil and improves soil health and contributes significantly to enhancing the yield of subsequent crops (Meena et al., 2012). However, the production and productivity is very low in green gram mainly due to its cultivation in resource poor lands with minimum inputs, non synchronous maturity and indeterminate growth habit. Green gram yield is also affected by insectpests and diseases, especially by green gram yellow mosaic virus (MYMV) and Cercospora leaf spot (CLS) (Table 1).

The front line demonstration (FLD) is an important method of transferring the latest package of practices in totality to farmers. Further, these demonstrations are designed carefully where provisions are made for speedy dissemination of demonstrated technology among farming community through organization of other supportive extension activities, such as field days and farmers convention. The main objective of the FLD is to demonstrate newly released crop production and protection technologies and management practices at the farmers' field under different agro-climatic regions and farming situations. Keeping in view, the present study was undertaken to increase the green gram productivity by conducting the FLDs.

\section{Materials and Methods}

The present on farm study was conducted during Kharif \& Summer 2016-17 and 201718 in Palamu district of Jharkhand under raifed conditions. Twenty farmers' field were randomly selected and sown three high yielding improved varieties of green gram namely IPA 02-03, SML668 and HUM16 in five replication with one check variety already grown by the farmers.. The package of improved technologies like line sowing, nutrient management, seed treatment and whole package were used in the demonstrations. The variety of green gram IPM-02- 3 was included in demonstrations methods used for the present study with respect to CFLDs and farmers' practices are given in Table 2. In case of local check plots, existing practices being used by farmers were followed. In general, soils of the area under study were medium to low in fertility status. The spacing was $30 \mathrm{~cm}$ between rows and 10 $\mathrm{cm}$ between plants in the rows. The thinning and weeding was done invariably 30-35 d after sowing to ensure recommended plant spacing within a row because excess population adversely affects growth and yield of crop. Other management practices were applied as per the package of practices. The data with respect to grain yield from CFLD plots and from fields cultivated following local practices adopted by the farmers of the area were collected and evaluated. Potential yield was taken in to consideration on the basis of standard plant population (404440 plants/ ha) and average yield per plant 22.5 $\mathrm{g} /$ plant under recommended package of practices with $30 \times 10 \mathrm{~cm}$ crop geometry (Chandra, 2010). Various field data like average number of nodules/plant, plant height, number of branches, number of pods/plant and yield were recorded at harvest. Different parameters as suggested by Yadav et al (2004) was used for gap analysis, and calculating the economic. To estimate the technology gap, extension gap and technology index formula given by Samui et al., (2000) was used i.e.

Extension gap $=$ Demonstration yield Farmers' practice yield

Technology gap = Potential yield Demonstration yield 


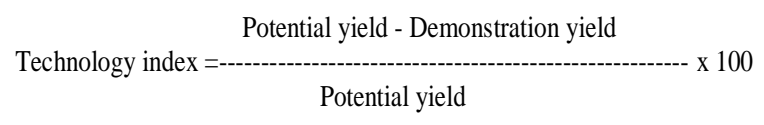

\section{Results and Discussion}

\section{Yield attributing traits}

The data (Table 3) indicated that maximum number of modules found in IPM 02-03 which were significantly superior over other varieties and farmers' practice. This might be due to decrease in adsorption/fixation and enhanced phosphorus availability with application of organic manures resulting in better growth and consequently exploitation of greater soil volume for modulation as reported by Choudhary et al., (2011). The tallest plant height was recorded in variety
HUM16 (47.3 cm) followed by SML668 $(46.8 \mathrm{~cm})$ and IPM $02-03(45.2 \mathrm{~cm})$. The varieties SML668 produced maximum number of branches per plant (9.7) followed by IPM 02-03 (9.6). The reason may be attributed to the genetic variability and varietal difference and environmental adaptability. Similar results were reported by Samant (2014) in green gram.

The variety IPM 02-03 recorded maximum number of pods/plant which was significantly higher with variety SML668 (34.6). The positive effect of phosphorus application on number of pods/plant might be due to better enzymatic activities which control flowering and pod formation (Kumar and Singh, 2014).

Table.1 Production of pulses in India

\begin{tabular}{|l|c|c|c|c|c|c|}
\hline Pulses/Year & $\mathbf{2 0 1 4 - 1 5}$ & $\begin{array}{c}\text { \% Share in } \\
\text { Total } \\
\text { production }\end{array}$ & $\begin{array}{c}\mathbf{2 0 1 5 - 1 6} \\
\text { \% Share } \\
\text { in }\end{array}$ & $\begin{array}{c}\text { Total } \\
\text { production }\end{array}$ & $\mathbf{2 0 1 6 - 1 7 *}$ & $\begin{array}{c}\text { \% Share in } \\
\text { Total } \\
\text { production }\end{array}$ \\
\hline Urd & 1960.00 & 11.42 & 1950.00 & 11.92 & 2890.00 & 13.05 \\
\hline Moong & 1500.00 & 8.74 & 1590.00 & 9.72 & 2130.00 & 9.62 \\
\hline Tur & 2810.00 & 16.38 & 2560.00 & 15.65 & 4230.00 & 49.11 \\
\hline Gram & 7330.00 & 42.74 & 7060.00 & 43.18 & 9120.00 & 41.20 \\
\hline Other Pulses & 3550.00 & 26.69 & 3190.00 & 19.52 & 3770.00 & 17.03 \\
\hline Total Pulses & 17150.00 & & 16350.00 & & 22140.00 & \\
\hline
\end{tabular}

Source: Directorate of Economics and Statistics (DES)*: Based on $2^{\text {nd }}$ Advance Estimates for 2016-17

Table.2 Particulars showing the details of green gram grown under CFLD and farmers' practice

\begin{tabular}{|c|c|c|c|}
\hline Sr. No. & Cultural operation & Existing practice & Improved cultivation practice \\
\hline 1. & Variety & Local seed & IPA 02-03, SML 668 and HUM16 \\
\hline 2. & Seed rate & $25-30 \mathrm{~kg} / \mathrm{ha}$ & $30 \mathrm{~kg} / \mathrm{ha}$ \\
\hline 3. & Seed quality & Ungraded seed & Graded seed \\
\hline 4. & Seed treatment & No seed treatment & $\begin{array}{l}\text { Treated with bavistin followed by } \\
\text { Rhizobium }\end{array}$ \\
\hline 5. & Method of sowing & Broadcasting & Line sowing by seed drill \\
\hline 6. & $\begin{array}{l}\text { Fertilizer } \\
\text { application }\end{array}$ & - & $\begin{array}{l}110 \mathrm{~kg} \text { DAP + } 40 \mathrm{~kg} \mathrm{MOP}+12 \mathrm{Kg} \text { Urea } \\
\text { per ha. }\end{array}$ \\
\hline 7. & $\begin{array}{l}\text { Plant protection } \\
\text { measures }\end{array}$ & - & Chlorpyriphos $20 \%$ EC \\
\hline
\end{tabular}


Table.3 Performance of varieties on growth parameters, yield attributes and yields of green gram. (Pooled data over two years)

\begin{tabular}{|c|c|c|c|c|c|c|c|c|c|c|c|c|c|c|}
\hline \multirow[t]{2}{*}{ Treatment } & \multicolumn{2}{|c|}{ Nodules } & \multicolumn{2}{|c|}{$\begin{array}{c}\text { Plant } \\
\text { height }(\mathbf{c m})\end{array}$} & \multicolumn{2}{|c|}{$\begin{array}{c}\text { No. of } \\
\text { Branches }\end{array}$} & \multicolumn{2}{|c|}{$\begin{array}{c}\text { No. of pods/ } \\
\text { plant }\end{array}$} & \multicolumn{2}{|c|}{$\begin{array}{l}\text { No. of grain/ } \\
\text { pod }\end{array}$} & \multicolumn{2}{|c|}{$\begin{array}{c}\text { Disease } \\
\text { incidence }(\%)\end{array}$} & \multicolumn{2}{|c|}{ Yield (q/ha.) } \\
\hline & 2016 & 2017 & 2016 & 2017 & 2016 & 2017 & 2016 & 2017 & 2016 & 2017 & 2016 & 2017 & 2016 & 2017 \\
\hline $\begin{array}{l}\text { Famers' } \\
\text { practice }\end{array}$ & 6.6 & 6.5 & 41.2 & 40.2 & 7.5 & 7.8 & 29.3 & 29.5 & 11.3 & 11.6 & 17.2 & 15.4 & 11.5 & 11.80 \\
\hline IPM 02-03 & 12.6 & 12.4 & 45.2 & 46.2 & 9.6 & 9.9 & 38.1 & 38.3 & 12.8 & 12.9 & 6.6 & 6.2 & 15.7 & 16.72 \\
\hline SML668 & 11.4 & 11.5 & 46.8 & 48.3 & 9.7 & 10.1 & 34.6 & 34.8 & 12.9 & 13.0 & 7.9 & 7.6 & 14.2 & 14.90 \\
\hline HUM16 & 9.8 & 10.1 & 47.3 & 48.5 & 8.8 & 8.7 & $32 . .1$ & 31.5 & 12.3 & 12.5 & 8.6 & 8.1 & 13.5 & 13.77 \\
\hline CD $P<(0.05)$ & 2.02 & 2.05 & 1.28 & 1.32 & NS & NS & 4.34 & 4.37 & $0.92 *$ & $0.93 *$ & 1.94 & 1.89 & 1.17 & 1.27 \\
\hline
\end{tabular}

Table.4 Yield, technology gap, extension gap and technology index of green gram

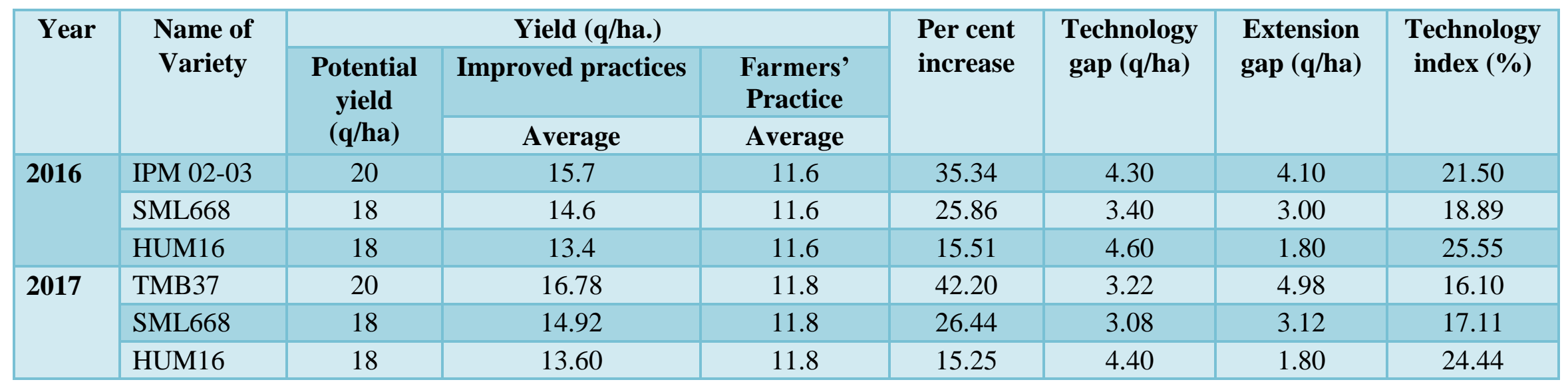


The variety SML668 recorded maximum number of grain/ pod (12.9) and significantly superior to IPM 02-03 (12.8). The reason may be attributed towards the genetic variability and grain size. Farmers' check variety had minimum grain/ pods $(11.3,11.6)$. The data (Table 3) showed that disease incidence (\%) ranged between 6.2 to 8.6 per cent in three varieties whereas; the farmers' practice recorded 15.4 to 17.2 per cent during both years. Almost same trend was recorded in the subsequent years.

\section{Seed yield}

The productivity of green gram under improved production technology ranged between $13.5-16.72 \mathrm{q} / \mathrm{ha}$ with mean yields of $15.11 \mathrm{q} / \mathrm{ha}$ (Table 4). In comparison to farmer's practice, there was an increase in productivity of green gram under improved technologies. The increased grain yield with improved technologies was mainly because of line sowing use of nutrient management and weed management. The findings were in line with Singh and Meena (2011), Poonia and Pithia (2011), Meena et al., (2012).

The maximum yield of green gram was recorded in IPM 02-03 which was significantly superior to SML668 in both the years. However, HUM16 recorded highest yield in comparison to farmers' practice. Thus, the local variety/farmers' practice may be replaced with high yielding varieties because of higher productivity.

\section{Gap analysis}

The technology gap ranged between 3.40 to 4.60 and 3.22 to $4.40 \mathrm{q} / \mathrm{ha}$ in 2016 and 2017, respectively. The observed technology gap was due to various constraints such as soil fertility, availability of low moisture content and climatic hazards etc. Hence, to reduce the yield gap location specific recommendations for varieties, soil testing and timely sowing appears to be necessary. A value of 1.80 to $4.10 \mathrm{q} / \mathrm{ha}$ of extension gap was found in 2016 whereas it was 1.80 to $4.98 \mathrm{q} /$ ha during 2017 . There is a need to decrease this wider extension gap through latest techniques. These findings were similar to the findings of Jain (2016) and Kushwah et al., (2016). The technology index showed the suitability of varieties at farmer's field. Lower technology values indicated that feasibility of variety among the farmers is more. The technology index ranged from 18.89 to 25.55 per cent. The finding was in accordance to finding of Sandhu and Dhaliwal (2016).

In conclusion the CFLD produces a significant positive result and provided the researcher an opportunity to demonstrate the productivity potential and profitability of the latest technology (Intervention) under real farming situation, which they have been advocating for long time. This could be circumventing some of the constraints in the existing transfer of technology system in the district. The productivity gain under CFLD over existing practices of Green Gram cultivation created greater awareness and motivated the other farmers to adopt suitable production technology of Green Gram in the district. This technology is suitable and acceptability to all the farmers group during Kharif and summer season. The findings of the study concluded that the yield of IPM 0203 was significantly higher than other varieties with recommended package and practices of green gram. Thus, the farmer's practice variety may be replaced with high yielding varieties like IPM 02-03 and SML668 in Palamu district of Jharkhand.

It may be concluded that the frontline demonstrations conducted on greengram at the farmers' field revealed that the adoption of improved technologies significantly increased the yield as well as yield attributing 
traits of the crop and also the net returns to the farmers. Hence, there is a need to disseminate the improved technologies among the farmers with effective extension methods like training and demonstrations. The farmers' should be encouraged to adopt the recommended package of practices for realizing higher returns.

\section{References}

Chandra G (2010). Evaluation of frontline demonstrations of greengram in Sunderban, West Bengal. J Indian Soc Costal Agril Res., 28:12-15.

Choudhary H R, Sharma, O P, Yadav L R and Choudhary G I (2011).Effect of organic sources and chemical fertilizers on productivity of Mungbean. $J$ Food Legumes, 24: 324- 326.

Jain L K (2016). Impact assessment of frontline demonstration on green gram in Barmer district of Western Rajasthan. J Food Legumes, 29(3 \& 4): 249-252.

Kumar S and Singh R N (2014). Effect of vermicompost and Rhizobium application on productivity of Mungbean sown after wheat. $R A U$ Journal of Res 24(1-2): 26-28.

Kushwah S, Kumar S and Singh S R K (2016). Adoption of improved late sown mustard cultivation practices - A case study in Bihar. $J$ Community Mobilization and Sustainable Dev.,
11(1): 19-23.

Meena M L and Dudi A (2012). On farm testing of chickpea cultivars for site specific assessment under rainfed condition of western Rajasthan. Indian $J$ Ext Edu., 48 (3\&4): 93-97.

Poonia T C and Pithia M S (2011). Impact of front line demonstrations on chickpea in Gujrat. Legume Res., 34(4): 304-307.

Samant T K (2014). Evaluation of growth and yield parameters of green gram. Agriculture Update, 9(3):427-430.

Samui, S K, Maitra S, Roy D R, Mondal A K and Saha D (2000). Evaluation of frontline demonstration programme on groundnut. J Indian Society Coastal Agril Res., 18 (2): 180-183.

Sandhu B S and Dhaliwal N S (2016). Evaluation of frontline demonstration programme on summer moong in South Western Punjab. J Food Legumes, 29 (3 \& 4): 245-248.

Singh D and Meena M L (2011). Boosting seed spices production technology through front line demonstrations. Int $J$ Seed Spices, 1(1): 81-85.

Yadav D B, Kambhoj B K and Garg R B (2004). Increasing the productivity and profitability of sunflowers through frontline demonstrations in irrigated agro-ecosystem of eastern Haryana. Haryana J Agron., 20(1): 33-35.

\section{How to cite this article:}

Rajiv Kumar. 2020. Assessment of Green Gram Varieties for Better Yield in Palamu District of Jharkhand, India. Int.J.Curr.Microbiol.App.Sci. 9(09): 1653-1658.

doi: https://doi.org/10.20546/ijcmas.2020.909.205 